\author{
PAWEŁ CZAPLIŃSKI \\ Uniwersytet Szczeciński, Polska \\ University of Szczecin, Poland
IGOR KAVETSKYY
Uniwersytet Szczeciński, Polska
University of Szczecin, Poland

\title{
Przestrzenny wymiar funkcjonowania i rozwoju energetyki odnawialnej na Ukrainie
}

\section{Spatial Dimension of Functioning and Development of the Renewable Energy Sector in Ukraine}

\begin{abstract}
Streszczenie: Celem pracy jest ocena osiągniętego poziomu rozwoju energetyki odnawialnej na Ukrainie ze szczególnym akcentem na przestrzenny wymiar jej funkcjonowania. W zakresie autorskich dociekań znalazły się m.in. kwestie przestrzennej struktury oszacowanego potencjału technicznego odnawialnych źródeł energii (OZE), zróżnicowania przestrzennego produkcji energii ze źródeł odnawialnych oraz polityki wspierania inwestycji w energetykę odnawialną i popularyzacji wiedzy o OZE na Ukrainie. Materiał do badań pochodzi z ogólnodostępnych raportów analitycznych, roczników i opracowań statystycznych publikowanych przez specjalistyczne agencje rządowe i międzynarodowe oraz instytucje naukowe. Dane źródłowe są analizowane z wykorzystaniem podstawowych narzędzi statystyki opisowej oraz metod analizy przestrzennej. Jak wynika z przeprowadzonych badań, znaczenie OZE w miksie energetycznym Ukrainy jest nadal znikome. Dotyczy to wykorzystania potencjału technicznego, mocy zainstalowanej oraz udziału w strukturze produkcji energii. Rozkład przestrzenny produkcji energii ze źródeł odnawialnych wykazuje znaczące zróżnicowanie, będące konsekwencją zróżnicowania jego potencjału. Istotnym warunkiem dalszego rozwoju energetyki odnawialnej na Ukrainie jest dostępność źródeł finansowania. Niestety, państwowe wsparcie instytucjonalne, w tym finansowe, dla tego typu inwestycji jest bardzo ograniczone tak pod względem skali, formy i miejsca, jak również czasu finansowania.
\end{abstract}

\begin{abstract}
The purpose of this work is the evaluation of the level of development of renewable energy industry in Ukraine, with special emphasis on the spatial dimension of its functioning. The authors inquired, among others, the issues of spatial structure of the estimated RES (renewable energy sources) technical potential, spatial diversification of energy production based on renewable sources and policy of supporting investments in renewable energy, and popularising knowledge about RES in Ukraine. The research material comes from available analytical reports, yearbooks and statistical studies published by specialist governmental and international agencies as well as scientific institutions. Primary data were analysed using basic tools of descriptive statistics and spatial analysis methods. As it results from the conducted research, the significance of renewable energy in Ukraine's energy mix is still negligible. It applies to exploiting the technical potential, the installed power (capacity) and the participation in the structure of the energy production. The spatial distribution of energy production from renewable sources shows a significant diversity as a consequence of the diversification of its potential. In Ukraine, the availability of sources of finances is a substantial condition
\end{abstract}


for further development of renewable energy industry. Unfortunately, national institutional support, including financial one for this type of investment, is very limited in terms of scale, form and location, as well as funding time.

Słowa kluczowe: energetyka odnawialna; odnawialne źródła energii; struktura przestrzenna; Ukraina Keywords: renewable energy; renewable energy sources; spatial structure; Ukraine

Otrzymano: 11 stycznia 2019

Received: 11 January 2019

Zaakceptowano: 9 lipca 2019

Accepted: 9 July 2019

\section{Sugerowana cytacja / Suggested citation:}

Czapliński, P., Kavetskyy, I. (2019). Przestrzenny wymiar funkcjonowania i rozwoju energetyki odnawialnej na Ukrainie. Prace Komisji Geografii Przemysłu Polskiego Towarzystwa Geograficznego, 33(4), 114-131. doi: $10.24917 / 20801653.334,7$

\section{WSTĘP}

Obserwowany kryzys gospodarczy na Ukrainie, potęgowany konfliktem zbrojnym w jej wschodniej części, uwidocznił zaległości infrastrukturalne i organizacyjne w całym sektorze energetycznym. Jak słusznie podkreśla Z. Nowak (2015), do słabości ukraińskiej energetyki należą duża energochłonność gospodarki, krytyczne uzależnienie od dostaw surowców z Rosji, niska elastyczność systemu energetycznego oraz niedocenianie odnawialnych źródeł energii (OZE). Na uwarunkowania krajowe nakładają się również trendy światowe, takie jak permanentny wzrost popytu na energię przy ograniczonych, kurczących się zasobach źródeł konwencjonalnych, a co za tym idzie, wzrost ich ceny.

Zgodnie z danymi Państwowej Służby Statystyki Ukrainy (DSSU, 2018a) w strukturze zaopatrzenia kraju w energię pierwotną stale utrzymuje się decydująca rola trzech źródeł, jakimi są: węgiel i torf $(32,4 \%$ w 2016 roku), gaz ziemny $(27,9 \%)$ oraz energia jądrowa $(23,2 \%)$, z jednoczesną tendencją do zwiększenia udziału ostatniej oraz malejącej roli paliwa gazowego. W tym samym czasie na wysokim poziomie pozostaje zależność od zewnętrznych dostaw nośników energii. Wskaźnik importu energii brutto, mimo że zmalał w stosunku do rekordowych 77,5\% w 2008 roku, oscyluje w ostatnich latach wokół 50\%. Warto podkreślić, że od 2007 roku Ukraina ograniczyła o jedną trzecią zapotrzebowanie na surowce energetyczne, przede wszystkim na gaz ziemny. Wydaje się jednak, że ta redukcja była bardziej skutkiem sytuacji politycznej aniżeli przemyślanej polityki energetycznej. Energochłonność ukraińskiej gospodarki nadal jest dwukrotnie większa od średniej światowej oraz trzykrotnie przekracza analogiczny wskaźnik dla UE (IEA, 2018).

Rola OZE w energetycznym koszyku Ukrainy jest znikoma. Energia pozyskana ze źródeł odnawialnych stanowiła na początku 2017 roku zaledwie 3,9\% energii pierwotnej ogółem (DSSU, 2018b). Jest to problem na tyle istotny, iż bazowanie systemu energetycznego na nośnikach konwencjonalnych już teraz przysparza wiele trudności, związanych zasadniczo z aktualnym stanem infrastruktury. Według oficjalnych danych (Zakonodavstvo Ukrayiny, 2013) na początku 2013 roku aż 81\% jednostek wytwórczych elektrowni oraz elektrociepłowni przekroczyło granicę 200 tys. godzin pracy i powinno być poddane modernizacji lub wycofane. Z kolei ponad $70 \%$ bloków jądrowych miało wymagać przedłużenia okresu eksploatacji w ciągu najbliższych 
10 lat. Można jeszcze wspomnieć o 42,2\% linii przesyłowych o napięciu 220-330 kV użytkowanych od ponad 40 lat oraz o 64,4\% podstawowego wyposażenia stacji transformatorowych, którego stan techniczny znacznie przekracza zakładany czas bezpiecznej eksploatacji. Do dziś sytuacja uległa dalszemu pogorszeniu, na co wskazują informacje Narodowej Komisji ds. Regulacji Energetyki i Usług Komunalnych (por. NKPEKP, 2018a).

W takich warunkach za jeden z kluczowych priorytetów dalszego funkcjonowania sektora energetycznego władze ukraińskie uznały rozwój energetyki odnawialnej. Nie mniej ważne w tym kontekście były również międzynawowe zobowiązania Ukrainy dotyczące OZE i zapobiegania zmianom klimatu, wynikające m.in. z ratyfikowanej jeszcze w 1996 roku ramowej konwencji Organizacji Narodów Zjednoczonych w sprawie zmian klimatu czy też przystąpienia w 2011 roku do Wspólnoty Energetycznej oraz wejścia w życie w 2017 roku umowy stowarzyszeniowej pomiędzy Ukrainą a UE, zakładającej stopniowe wdrożenie 29 rozporządzeń i dyrektyw związanych z kwestiami środowiskowymi. Najważniejszy dokument w tym zakresie - strategia energetyczna Ukrainy do 2035 roku Bezpieczeństwo, efektywność energetyczna, konkurencyjność (Zakonodavstvo Ukrayiny, 2017) - przewiduje znaczący postęp w dziedzinie OZE przez zwiększenie ich udziału w pozyskaniu energii pierwotnej do 8\% już w 2020 roku. Wartość ta jest traktowana jako równoznaczna z osiągnięciem 11-procentowego udziału OZE w końcowym zużyciu energii, który został zadeklarowany przez Ukrainę w ramach członkostwa we Wspólnocie Energetycznej (EnC, 2012) oraz potwierdzony w realizowanym obecnie Krajowym planie działań w zakresie energetyki odnawialnej do 2020 roku (Zakonodavstvo Ukrayiny, 2014). Docelowo w 2035 roku energia ze źródeł odnawianych powinna stanowić $25 \%$ zaopatrzenia kraju w energię pierwotną. Przyjęcie takiego scenariusza wynika m.in. z oceny potencjału OZE, którego istotne rezerwy tkwią we wszystkich ukraińskich regionach.

W związku z powyższym za główny cel niniejszej pracy przyjęto ocenę osiągniętego poziomu rozwoju energetyki odnawialnej na Ukrainie, ze szczególnym akcentem na przestrzenny wymiar jej funkcjonowania. Praca zmierza m.in. do udzielenia odpowiedzi na następujące pytania:

- jak kształtuje się przestrzenna struktura oszacowanego potencjału technicznego energii możliwej do pozyskania z OZE;

- jakie są charakterystyczne cechy zróżnicowania przestrzennego produkcji energii ze źródeł odnawialnych;

- jak przedstawia się polityka wspierania inwestycji w energetykę odnawialną oraz popularyzacji wiedzy o OZE.

Materiały do badań pochodzą z ogólnodostępnych raportów analitycznych, roczników i opracowań statystycznych publikowanych przez specjalistyczne agencje rządowe i międzynarodowe oraz instytucje naukowe. Dane źródłowe są analizowane z wykorzystaniem podstawowych narzędzi statystyki opisowej oraz metod analizy przestrzennej. Ze względu na specyfikę lub dostępność stosownych danych szczegółowa analiza produkcji energii ze źródeł odnawialnych została ograniczona do sektora przedsiębiorstw elektroenergetycznych (z wyłączeniem dużych elektrowni wodnych i szczytowo-pompowych) i nie uwzględnia wytwarzania ciepła, jak również pomija instalacje systemów energii odnawialnej w indywidualnych gospodarstwach domowych. 


\section{POTENCJAŁ ODNAWIALNYCH ŹRÓDEŁ ENERGII}

Wielkość potencjału technicznego OZE, możliwa do pozyskania w ciągu roku na Ukrainie, zgodnie z danymi Państwowej Agencji Efektywności Energetycznej i Energooszczędności Ukrainy (DAEEU, 2018a), jest szacowana na 68,9 mln t ekwiwalentu ropy naftowej (Mtoe) na rok. Jest on obecnie wykorzystywany zaledwie w 5\% (Tsentr Razumkova, 2018), podczas gdy jego pełne użycie umożliwiłoby niemal 50-procentowe zastąpienie tradycyjnych paliw kopalnych (Sukhodolya, Smenkovskyy, Shevstov, Zemlyanyy, 2014). Szczególnie istotnymi źródłami energii odnawialnej są bioenergia, energia wiatru oraz energia otoczenia (środowiska naturalnego). Łącznie stanowią one 78,5\% ogólnego potencjału OZE (rycina 1).

Rozkład przestrzenny potencjału OZE wykazuje znaczące zróżnicowanie, zarówno gdy chodzi o jego wielkość sumaryczną, jak i strukturę rodzajową (rycina 2). Największe wartości potencjału związane są z południową i południowo-wschodnią częścią kraju. Łączny udział sześciu regionów (Autonomiczna Republika Krymu oraz obwody zaporoski, doniecki, chersoński, mikołajowski i dniepropetrowski), w każdym z których roczny potencjał OZE sięga 4 Mtoe i więcej, stanowi 43,2\% wielkości krajowej. To właśnie tu występują najkorzystniejsze warunki do pozyskiwania energii wiatru oraz promieniowania słonecznego (niemal 3/4 potencjału wiatrowego i ponad 1/2 potencjału solarnego kraju). Jakkolwiek nie można zapomnieć, że istotna część z tych zdolności jest obecnie niedostępna dla Ukrainy ze względu na sytuację polityczną na Krymie i w Donbasie.

Potencjał energii otoczenia oraz potencjał bioenergetyczny nie wykazują tak znacznego zróżnicowania, niemniej wyższe wartości osiągają one w części środkowej i wschodniej kraju. Jeśli chodzi o pozostałe alternatywne źródła energetyczne, to należy wspomnieć o energii małych rzek i strumieni, której największe rezerwy są skoncentrowane w regionach karpackich (ponad 60\% potencjału wód płynących, w tym 36,3\% na Zakarpaciu) oraz energii geotermalnej, dla której szczególnie dobre warunki występują w północno-wschodniej części kraju, na tzw. Ukrainie Słobodzkiej (ponad 1/4 potencjału geotermalnego kraju).

Wskazany potencjał w perspektywie długookresowej winien przynieść Ukrinie wymierne korzyści. Istnieje jednak wiele czynników, zwłaszcza pozarynkowych, których ostateczny wpływ na ukraiński rynek energetyczny jest trudny do ustalenia (por. Kost, 2017, 2018). Stąd duże rozbieżności w możliwych scenariuszach dalszego rozwoju (tabela 1). Wydaje się jednak, że mimo wielu niekorzystnych uwarunkowań wewnętrznych i zewnętrznych, pierwotnie przewidywany przez rząd (prognoza I) niemal trzykrotny wzrost produkcji energii ze źródeł odnawialnych w stosunku do roku 2009 jest uzasadniony. Późniejsze oceny eksperckie (prognozy II-IV), bazujące na założeniu o dalszym umiarkowanym tempie rozwoju sektora, są zdecydowanie bardziej optymistyczne.

Szczególnie istotnym źródłem pozyskiwania energii odnawialnej ma być energia wiatru. Nie można jednak zapomnieć, że rozwój energetyki wiatrowej w dużej mierze zależeć będzie od ostatecznych rozstrzygnięć konfliktu ukraińsko-rosyjskiego, ponieważ to na obszarach spornych (Krym, Donbas) istnieją najlepsze warunki dla jej rozwoju. Wszystkie scenariusze utrzymują na niemal niezmiennym poziomie znaczenie hydroenergetyki reprezentowanej zasadniczo przez istniejące od lat kaskady dużych 
Rycina 1. Potencjał techniczny odnawialnych źródeł energii

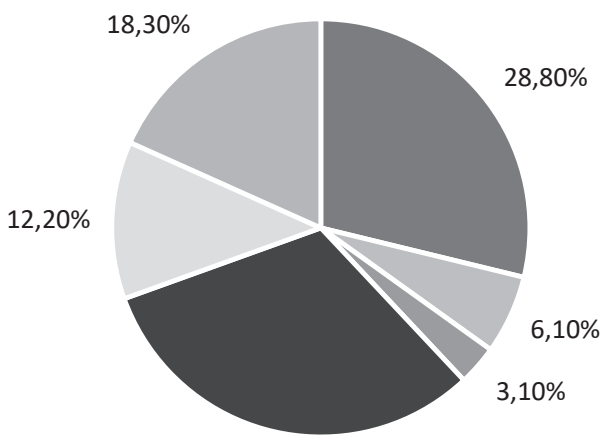

$31,50 \%$

- energia wiatru

- energia małych cieków wodnych

- energia geotermalna
- energia słoneczna

- bioenergia

- energia otoczenia (środowiska naturalnego)

Źródło: opracowanie własne na podstawie danych DAEEU (2018a)

Rycina 2. Struktura przestrzenna potencjału odnawialnych źródeł energii

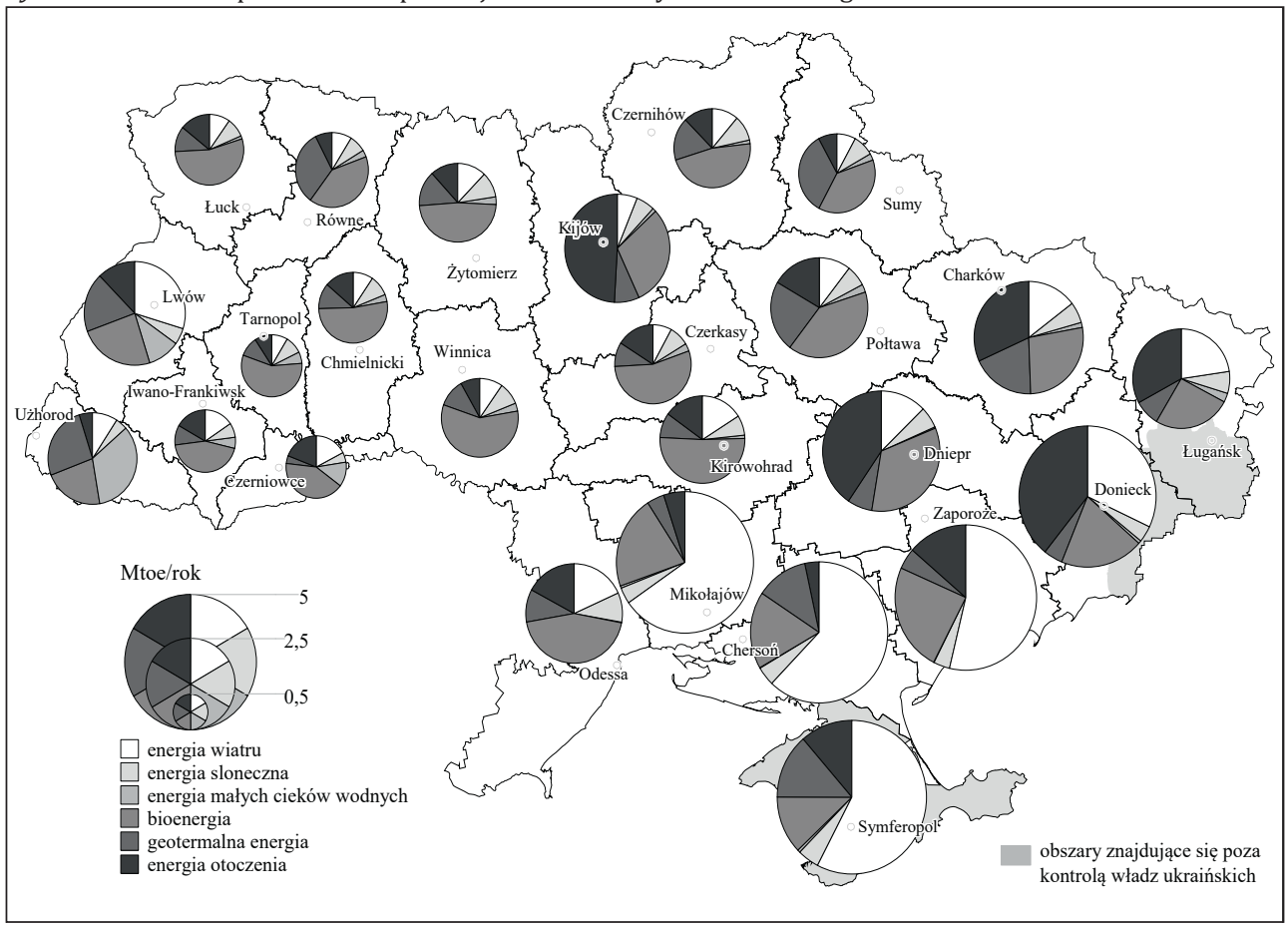

Źródło: opracowanie własne na podstawie Sukhodolya, Smenkovskyy, Shevstov, Zemlyanyy (2014) 
elektrowni wodnych na Dnieprze i Dniestrze. Jeśli chodzi o małą energetykę wodną (siłownie o mocy do 10MW), to poza regionem Karpat osiągnęła ona już wartości brzegowe i jej dalszy rozwój może skutkować rosnącymi kosztami względnymi. Zdecydowany wzrost znaczenia bioenergetyki akcentuje zwłaszcza prognoza IRENA, natomiast Instytut Ekonomii i Prognoz szczególnie docenia możliwości konwersji na energię elektryczną energii promieniowania słonecznego. Najmniej korzystna prognoza dotyczy energetyki geotermalnej. Wiąże się to nie tyle z relatywnie małym potencjałem, ile z wysokim kosztem inwestycji oraz barierą infrastrukturalną, która jak na razie uniemożliwia szerokie wykorzystanie tego typu energii.

Tabela 1. Prognozy wykorzystania OZE do produkcji energii elektrycznej (w TWh/rok) w 2030 roku

\begin{tabular}{|l|c|c|c|c|c|}
\hline \multicolumn{1}{|c|}{$\begin{array}{c}\text { Rodzaje energii } \\
\text { odnawialnej }\end{array}$} & $\begin{array}{c}\text { Stan na 2009 } \\
\text { rok }\end{array}$ & $\begin{array}{c}\text { Prognoza } \\
\text { I }\end{array}$ & Prognoza II & Prognoza III & Prognoza IV \\
\hline energia wiatru & 0,0 & 7,8 & 34,7 & 30,0 & 22,0 \\
\hline energia słoneczna & - & 2,6 & 8,4 & 4,9 & 12,0 \\
\hline energia wody & 11,4 & 14,5 & 14,5 & 14,5 & 12,6 \\
\hline bioenergia & 0,1 & 7,0 & 13,2 & 7,0 & 5,0 \\
\hline energia geotermalna & - & 0,1 & 0,1 & 3,0 & 0,4 \\
\hline Razem & 11,6 & 32,1 & 70,9 & 59,4 & 52,0 \\
\hline
\end{tabular}

Uwagi: Prognoza I - Państwowa Agencja Efektywności Energetycznej i Energooszczędności Ukrainy; prognoza II - Międzynarodowa Agencja Energii Odnawialnej (IRENA); prognoza III - Instytut Energetyki Odnawialnej (NAN) Ukrainy; prognoza IV - Instytut Ekonomii i Prognoz (NAN) Ukrainy

Źródło: opracowanie własne na podstawie IRENA (2015); MRR (2017); Oharenko, Aliyeva (2017)

\section{PRODUKCJA ENERGII ELEKTRYCZNEJ ZE ŹRÓDEŁ ODNAWIALNYCH}

Na koniec 2017 roku moc zainstalowana OZE na Ukrainie (bez uwzględnienia obszarów znajdujących się poza kontrolą rządu) osiągnęła wartość 7,4 GW, co stanowi 14,3\% łącznej mocy zjednoczonego systemu energetycznego (ZSE) kraju. Udział energii pochodzącej z odpowiednich źródeł wynosił 8,4\% ogólnej produkcji energii elektrycznej, dorównując 11,9 TWh. W tym miejscu należy jednak podkreślić ukraińską specyfikę sektora OZE, wynikającą z ogromnej dominacji energetyki wodnej (zasadniczo dużych elektrowni wodnych), na którą w latach 2010-2017 przypadało od 84 do 98,5\% wszystkich mocy odnawialnych oraz od około 80 do 97,7\% stosownej produkcji (NKPEKP, 2018a; Ukrenergo, 2018). W związku z wyłączeniem siłowni wodnych o mocy zainstalowanej powyżej $10 \mathrm{MW}$ z systemu taryf gwarantowanych, wspierających produkcję energii z OZE, duże elektrownie wodne faktycznie nie są traktowane w kategoriach energetyki odnawialnej i zwykle pomijane w specjalistycznych zestawieniach.

Przyjmując powyższe zastrzeżenie, należy podkreślić znaczący postęp Ukrainy w zakresie OZE w latach 2010-2017. Według oficjalnych danych (NKPEKP, 2018a) łączna moc zainstalowana OZE wzrosła niemal 13-krotnie, a produkcja energii z tych źródeł była w 2017 roku o 765,2\% większa niż w roku 2010. Średniookresowe tempo wzrostu wyniosło $44 \%$ w przypadku mocy oraz $36,1 \%$, jeśli chodzi o produkcję. Nie można jednak pominąć faktu, że aż 34\% wspomnianej mocy jest obecnie niedostępne dla Ukrainy z powodu jej ulokowania na niekontrolowanych obszarach Krymu i Donbasu. Spowolnienie w latach 2014-2015 spowodowane kryzysem politycznym i ekonomicznym wydaje się możliwe do nadrobienia w najbliższej przyszłości. Wprowadzone do użytku nowe moce 
wytwórcze za 10 miesięcy 2018 roku niemal dorównują tym utraconym, a produkcja już przekroczyła o 13,4\% poziom z 2017 roku (NKPEKP, 2018c).

Sektorem rozwijającym się najbardziej dynamicznie jest energetyka słoneczna, gdzie mamy do czynienia z 460-krotnym przyrostem mocy zainstalowanej oraz 1429-krotnym wzrostem produkcji. Szybkie tempo odnotowuje również bioenergetyka, w przypadku której moc osiągalna wzrosła o 1640,5\%, a produkcji o 2113,5\%. Niewiele niższą dynamikę wykazuje energetyka wiatrowa. W 2017 roku moc zainstalowana w tym sektorze stanowiła 721,8\%, a produkcja 1978,7\% poziomu z 2010 roku. W ten sposób w aktualnej strukturze wykorzystania OZE do produkcji energii elektrycznej na Ukrainie (bez uwzględnienia dużych elektrowni wodnych oraz pomijając obszary niekontrolowane) zdecydowanie umocniła się rola elektrowni wiatrowych i słonecznych, które kumulują ponad 86,6\% mocy wytwórczych (z wyraźną dominacją pierwszych) oraz 80,6\% wytwarzanej energii (z niewielką przewagą tych drugich) (rycina 3).

Produkcję energii elektrycznej ze źródeł odnawialnych cechuje duże zróżnicowanie przestrzenne. Jest ono naturalną konsekwencją zróżnicowania warunków przyrodniczych i techniczno-ekonomicznych na terenie kraju determinujących rozmieszczenie potencjału OZE. Ze względu na wyjątkowo sprzyjające warunki wiatrowe występujące na obszarach przyległych do Morza Czarnego i Morza Azowskiego oraz w nieco mniejszej mierze w rejonie Karpat właśnie tam powstały odpowiednie instalacje (rycina 4). Na koniec 2017 roku na Ukrainie funkcjonowało 29 elektrowni wiatrowych o łącznej mocy 552,9 MW, w tym dziewięć (87,8 MW) na Krymie i cztery (138 MW) na Donbasie. W ten sposób aż 40,8\% mocy zainstalowanej znalazło się poza ZSE Ukrainy. Zdecydowana większość siłowni to jednostki o mocy nieprzekraczającej $20 \mathrm{MW}$. Na tym tle znacząco wyróżnia się farma wiatrowa w Botijewie w obwodzie zaporoskim, której moc sięga aż $200 \mathrm{MW}$.

Pod względem organizacyjnym rynek producentów energii z wiatru reprezentowany był przez 14 odrębnych podmiotów gospodarczych. Biorąc jednak pod uwagę różnego rodzaju powiązania biznesowe i personalne, należy faktycznie mówić o zaledwie czterech dużych graczach. Największym z nich jest właściciel elektrowni w Botijewie, spółka Wind Power, należąca do koncernu Donbaska Kompania Paliwowo-Energetyczna (DTEK) Rinata Achmetowa, która zapewniła w 2017 roku aż 65,1\% energii wiatrowej dostarczonej do ZSE Ukrainy. Drugim tego typu graczem jest holding Spółka Zarządzająca Parki Wiatrowe Ukrainy, którego beneficjentem jest inny ukraiński miliarder, Oleg Mkrtczan. Z tą firmą związanych jest aż 11 elektrowni wiatrowych o łącznej mocy 218,5 MW, w tym wszystkie znajdujące się w obwodzie mikołajowskim i na Donbasie oraz jedna z siłowni krymskich - Park Wiatrowy Kerczeński (pozostałe krymskie elektrownie zostały znacjonalizowane przez nowe władze). Udział holdingu w produkcji energii wiatrowej wyniósł w 2017 roku 17,9\%. Z obwodem chersońskim wiąże się działalność grupy spółek Vindcraft, firmowanej przez szwedzkiego biznesmena Carla Sturena, której cztery elektrownie o łącznej mocy 34,4 MW wyprodukowały w 2017 roku 11,6\% energii. Z kolei działająca na terenie obwodu lwowskiego grupa Eco Optima z trzech swoich elektrowni o łącznej mocy 33,9 MW dostarczyła w 2017 roku do ZSE Ukrainy 5,1\% energii z wiatru.

Z danych Ukraińskiego Stowarzyszenia Energetyki Wiatrowej (UVEA, 2018) wynika, że rola dużych firm w tym sektorze będzie nadal wzrastała. Obecnie DTEK buduje dwie farmy wiatrowe o mocy 100 MW, każda w pobliżu Primorska w obwodzie 
Rycina 3. Łączna moc zainstalowana i produkcja energii elektrycznej ze źródeł odnawialnych w 2017 roku*

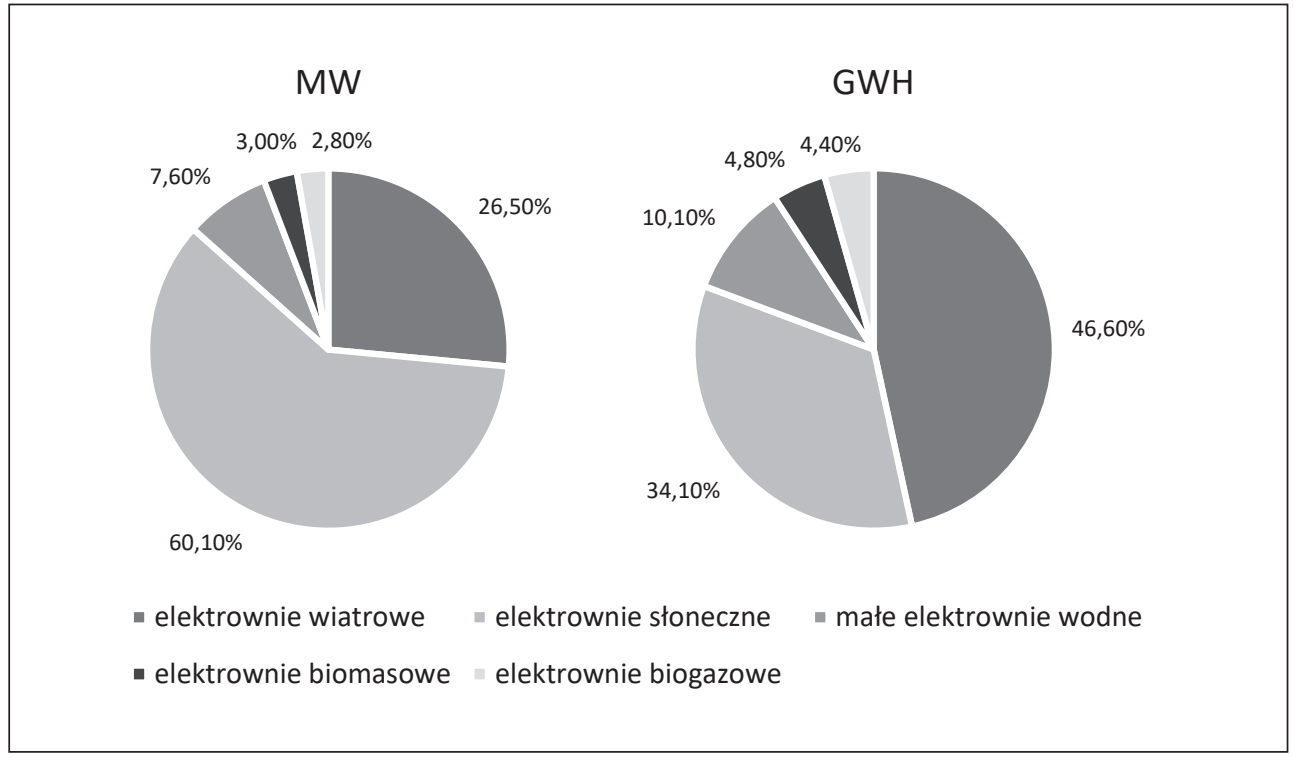

*Bez uwzględnienia dużych elektrowni wodnych oraz z wyłączeniem niekontrolowanych obszarów Krymu i Donbasu.

Źródło: opracowanie własne na podstawie danych NKPEKP (2018b)

Rycina 4. Elektrownie wiatrowe w 2017 roku*

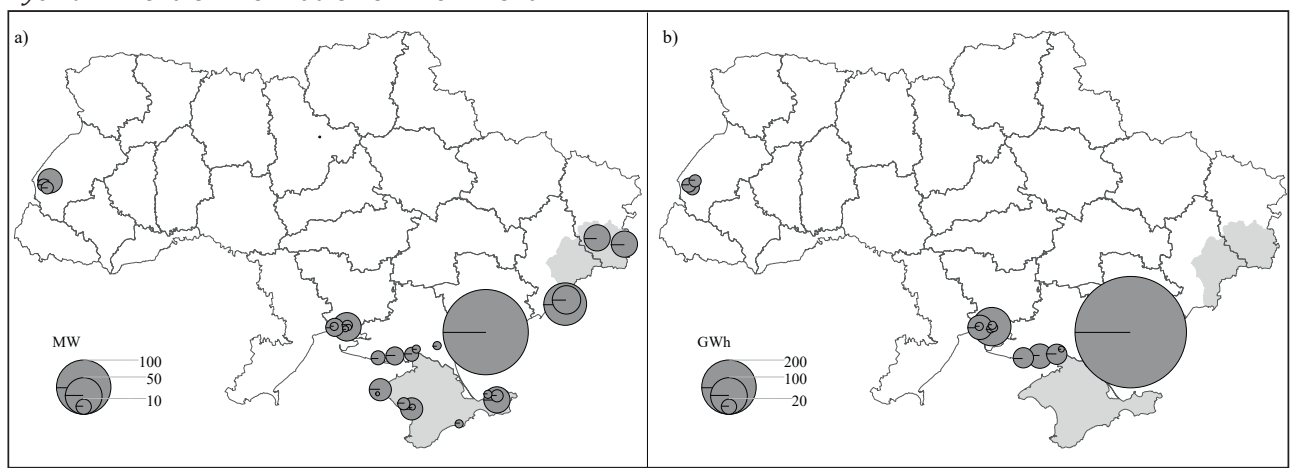

*a) moc zainstalowana; b) produkcja energii

Źródło: opracowanie własne na podstawie danych NKPEKP (2018b)

zaporoskim, a na 2019 rok zaplanowana jest budowa elektrowni w Orłówce (pomiędzy Botijewem a Primorskiem), której moc wytwórcza wyniesie również 100 MW. Holding Vindcraft już na początku 2018 roku przyłączył 40,2 MW mocy na farmie wiatrowej w Nowotroicku na Chersońszczyźnie, a do końca roku planowano wprowadzenie kolejnych 25,6 MW. Ponadto w trakcie budowy znajduje się pobliska elektrownia o mocy $69 \mathrm{MW}$ w Owerianowce, a w zaawansowanym stadium projektowym - farmy wiatrowe w Kałanczaku (300 MW), Czapłynce (300 MW) oraz Myrnem (160 MW). Warto jeszcze wspomnieć o dwóch projektach z deklarowaną mocą na poziomie $500 \mathrm{MW}$ każdy - elektrowni wiatrowej w rejonie berezańskim na Mikołajowszczyźnie, której budową 


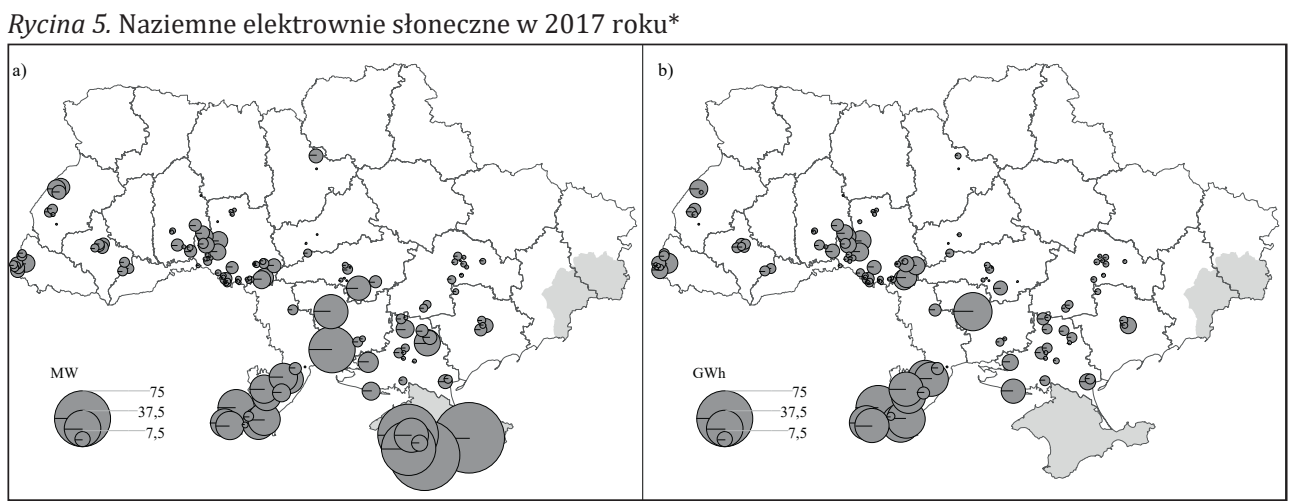

*a) moc zainstalowana; b) produkcja energii

Źródło: opracowanie własne na podstawie danych NKPEKP (2018b)

jest zainteresowany chiński inwestor Tebian Electric Apparatus, oraz farmy wiatrowej w rejonie pryazowskim na Zaporożu, którą planuje uruchomić międzynarodowa grupa EuroCape New Energy. Ogólnie w trakcie budowy lub projektowania, według stanu na koniec 2017 roku, znajdowało się 3271,9 MW mocy wytwórczych, tj. sześciokrotnie więcej niż moc aktualnie zainstalowana.

Rozmieszczenie elektrowni słonecznych charakteryzuje się zdecydowanie większym rozproszeniem, z wyraźnym wskazaniem na południowe i południowo-zachodnie regiony kraju (rycina 5). Na koniec 2017 roku na Ukrainie zarejestrowanych było aż 193 siłowni fotowoltaicznych (139 naziemnych oraz 54 dachowe i fasadowe) o łącznej mocy 741,9 MW, z której zaledwie 1,1\% przypadało na te drugie. Ponadto poza zasięgiem ZSE kraju pozostawało 407,1 MW mocy zainstalowanej przed 2014 rokiem na Krymie. Przeciętna moc instalacji naziemnych (bez uwzględnienia siłowni krymskich) wynosi 5,3 MW i tej wielkości nie przekracza ponad 70\% jednostek wytwórczych. Elektrownie duże, o mocy powyżej $20 \mathrm{MW}$, skupiają się zasadniczo na południu obwodu odeskiego (dziewięć siłowni) oraz w zachodniej części Mikołajowszczyzny (dwie jednostki). Aktualnie największa jest elektrownia fotowoltaiczna w Berezance w obwodzie mikołajowskim, której moc wynosi 53,4 MW.

Na liście producentów energii ze słońca na koniec 2017 roku znajdowało się 129 podmiotów gospodarczych, w tym 94 zarządzające instalacjami naziemnymi. Pomimo formalnego rozdrobnienia w tym sektorze również da się zidentyfikować kilka większych grup interesu (Uaenergy, 2018). Niekwestionowanym liderem jest tu chiński państwowy koncern CNBM New Energy Engineering Co, który przejął aktywa upadłej firmy Activ Solar, należącej do związanych z byłym prezydentem Ukrainy Wiktorem Janukowyczem braci Klujewów oraz będącej do 2014 roku faktycznym monopolistą na ukraińskim rynku energetyki słonecznej. To właśnie do chińskiego koncernu należą wszystkie duże elektrownie fotowoltaiczne o łącznej mocy 301,2 MW, co stanowi 40,6\% dostępnych mocy słonecznych i przekłada się na niemal 50\% udziału w wyprodukowanej w 2017 roku energii elektrycznej z promieniowania słonecznego.

Innym istotnym graczem jest grupa Rengy Development, związana z ukraińskim biznesmenem Andrijem Hordijenką, w której zasięgu znajduje się 12 siłowni o łącznej mocy 78,2 MW (10,5\% ogółu) w obrębie obwodów winnickiego, chersońskiego i odeskiego. W 2017 roku jej udział w produkcji energii słonecznej wyniósł 11,1\%. Tylko 
niewiele mniejszy (10,3 \%) okazał się wkład kolejnej grupy spółek, których rzeczywistym beneficjentem jest inny znany biznesmen, Serhij Chrypkow. Związane z tym nazwiskiem 10 elektrowni słonecznych działających na terenie obwodów winnickiego, chersońskiego i kirowohradzkiego skupiało na koniec 2017 roku 93 MW (12,5\%) odpowiednich mocy wytwórczych.

Zainteresowanie sektorem energetyki słonecznej wykazuje również wspominana wcześniej DTEK. W 2017 roku firma oddała do użytku swoją pierwszą (10 MW) siłownię fotowoltaiczną w Trifonowce w obwodzie chersońskim. Powstająca przy współudziale chińskiego koncernu China Machinery Engineering Corporation elektrownia słoneczna w pobliżu Nikopola w obwodzie dniepropietrowskim o mocy 200 MW może stać się jedną z największych elektrowni tego typu na świecie. Na koniec warto jeszcze wspomnieć o projektach rozbudowy instalacji fotowoltaicznych w strefie czarnobylskiej. W 2018 roku spółka Solar Chernobyl działająca w konsorcjum z ukraińską firmą Rodina Energy Group i niemiecką Enerparc AG uruchomiła siłownię 1 MW, która z czasem zostanie poszerzona do 100 MW. Docelowo w strefie wykluczenia planuje się rozmieszczenie instalacji słonecznych o łącznej mocy 1,2 GW.

Mała energetyka wodna na koniec 2017 roku reprezentowana była przez 137 elektrowni o łącznej mocy 95,6 MW, należących do 60 podmiotów gospodarczych. Większość mocy została zainstalowana na rzekach basenu Bohu (40,9\%), Dniestru (17\%) oraz na ciekach karpackich $(16,9 \%$ ) (rycina 6). Spomiędzy licznych właścicieli działających w tym sektorze na specjalną uwagę zasługują trzy przedsiębiorstwa, każde z nich posiada od 12 do 15 elektrowni: winnicka spółka Energoinwest, działająca głównie w obwodzie winnickim, kijowska spółka Gydroenergoinwest, koncentrująca się przede wszystkim na obwodzie kirowohradzkim, oraz firma Nowoswit z siedzibą w Winnicy, której działalność związana jest z regionem czerkaskim i chmielnickim. Ogólnie na trzy wspomniane spółki przypada 39,7\% całkowitej mocy zainstalowanej w małej energetyce wodnej oraz 41,4\% odpowiedniej produkcji energii elektrycznej.

Sektor bioenergetyczny jak na razie cechuje się najskromniejszymi osiągnięciami. Na koniec 2017 roku na Ukrainie działało 21 biogazowni (o łącznej mocy 34,4 MW) oraz sześć elektrowni na biomasę (38,7 MW) zarządzanych przez 18 właścicieli. Ich rozmieszczenie cechuje znaczące rozproszenie z niezbyt wyraźną tendencją do koncentracji w centralnej części kraju, ze szczególnym wskazaniem na region kijowski (rycina 7).

Rycina 6. Małe elektrownie wodne na Ukrainie w 2017 roku*

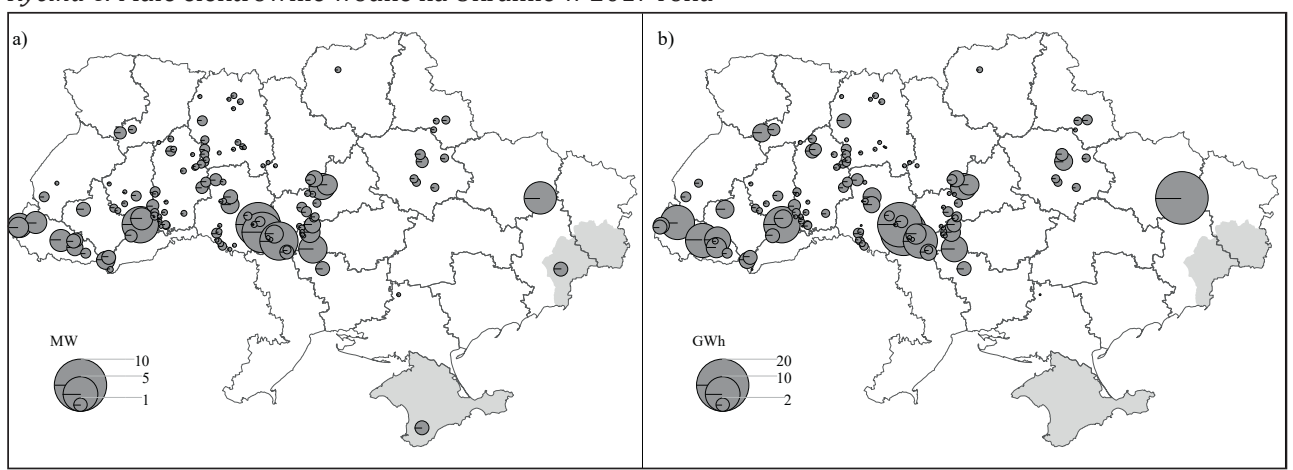

*a) moc zainstalowana; b) produkcja energii

Źródło: opracowanie własne na podstawie danych NKPEKP (2018b) 
Rycina 7. Bioelektrownie na Ukrainie w 2017 roku*

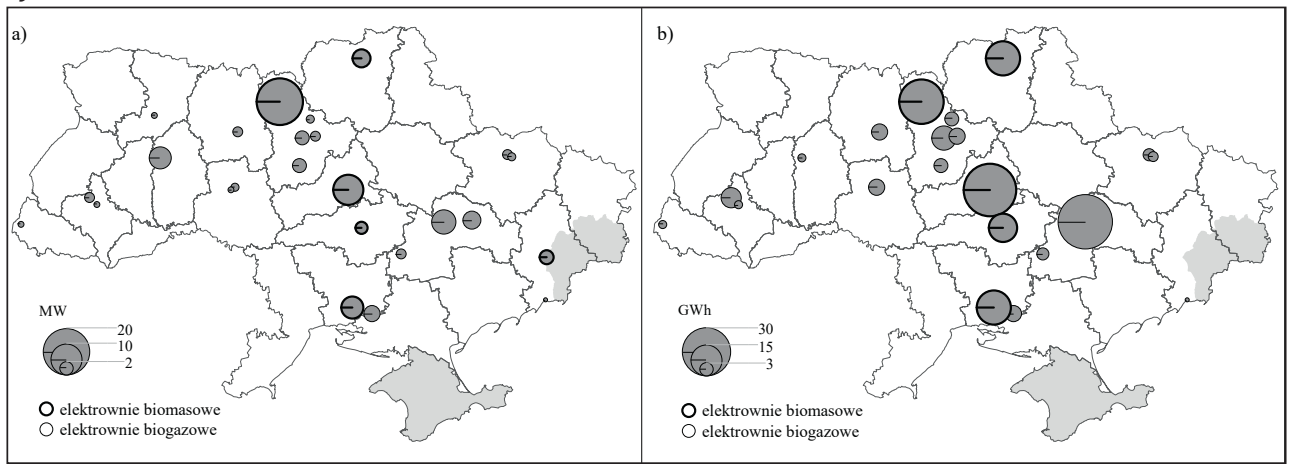

**a) moc zainstalowana; b) produkcja energii

Źródło: opracowanie własne na podstawie danych NKPEKP (2018b)

Rycina 8. Struktura przestrzenna mocy zainstalowanej OZE na koniec 2017 roku

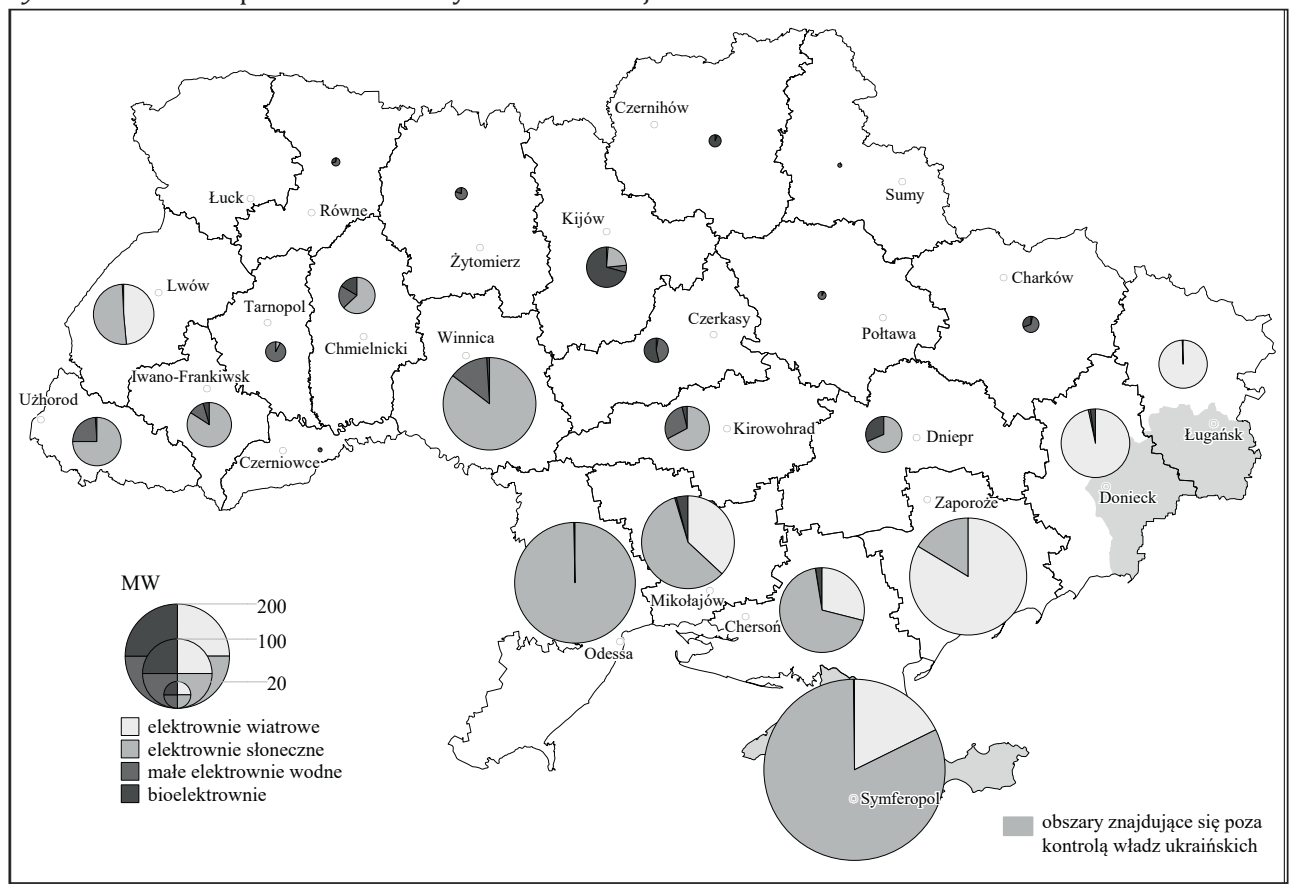

Źródło: opracowanie własne na podstawie danych NKPEKP (2018b)

Podsumowując powyższe rozważania, należy stwierdzić dość duże rozbieżności między strukturą przestrzenną potencjału OZE a jego dotychczasowym wykorzystaniem do produkcji energii elektrycznej w poszczególnych regionach kraju. W oparciu o sumaryczny wskaźnik mocy zainstalowanej według stanu na koniec 2017 roku (rycina 8) łatwo zaważyć zdecydowaną dominację w tym zakresie Autonomicznej Republiki Krymu, na którą przypada prawie 1/4 wszystkich zdolności wytwórczych. Niestety, są one od 2014 roku poza zasięgiem ukraińskiej gospodarki. Podobnie jak w przypadku obwodów donieckiego i ługańskiego, w których najważniejsze instalacje odnawialne 
powstały na terenach obecnie niekontrolowanych przez władze Ukrainy. Wśród liderów energetyki odnawialnej znalazły się przede wszystkim regiony nadczarnomorskie i nadazowskie, stawiające głównie na energię wiatru (obwód zaporoski) lub słońca (obwód odeski) albo na oba te źródła (regiony chersoński i mikołajowski). W sumie cztery wymienione regiony kumulują niemal 40\% zainstalowanych mocy wytwórczych.

Spośród innych regionów warto dostrzec pozycję obwodu winnickiego z udziałem $8,8 \%$ wynikającym z rozwoju siłowni fotowoltaicznych i małych elektrowni wodnych oraz, w mniejszej mierze, obwodu lwowskiego, w którym łączona jest energetyka wiatrowa i słoneczna. Regiony północne i północno-wschodnie jak na razie znajdują się faktycznie poza rynkiem energii odnawialnej.

\section{POLITYKA PAŃSTWA W ZAKRESIE ROZWOJU OZE}

Głównym instrumentem stymulowania rozwoju OZE stosowanym na Ukrainie od 2009 roku jest system taryf gwarantowanych, czyli ustalanych przez Narodową Komisję ds. Regulacji Energetyki i Usług Komunalnych stałych dopłat do produkcji energii elektrycznej pochodzącej z siłowni wiatrowych, słonecznych, geotermalnych, małych elektrowni wodnych (do $10 \mathrm{MW}$ ), elektrowni na biomasę oraz biogazowni (od 2013 roku). Państwo gwarantuje producentom energii elektrycznej z OZE zachowanie do 2030 roku stawek określonych w euro i aktualnych na dzień uruchomienia obiektów energetyki. Wysokość taryfy jest uzależniona od czasu oddania siłowni do użytku, rodzaju wykorzystywanej energii odnawialnej, a dla niektórych źródeł również od mocy instalacji (tabela 2). Stawki podlegają zwiększeniu w przypadku wykorzystania wyposażenia wyprodukowanego na Ukrainie: o 5\%, gdy udział elementów ukraińskiego pochodzenia wyniesie nie mniej niż 30\%, oraz o 10\%, jeżeli ten udział przekroczy 50\%.

Tabela 2. Wysokość taryfy gwarantowanej na energię elektryczną wyprodukowaną z OZE

\begin{tabular}{|c|c|c|c|c|c|c|}
\hline \multirow{3}{*}{$\begin{array}{c}\text { Rodzaj } \\
\text { elektrowni }\end{array}$} & \multirow{3}{*}{ Uszczegółowienie } & \multicolumn{5}{|c|}{ Taryfa według roku oddania do użytku* } \\
\hline & & $\stackrel{\text { L }}{\stackrel{0}{N}}$ & $\begin{array}{l}0 \\
\stackrel{1}{N}\end{array}$ & 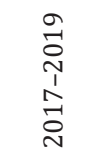 & 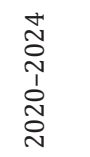 & 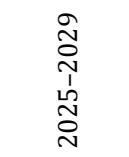 \\
\hline & & \multicolumn{4}{|c|}{$€ c t / k W h$} & kop./kWh \\
\hline \multirow{3}{*}{ wiatrowe } & do $600 \mathrm{~kW}$ & \multicolumn{3}{|c|}{5,81} & 5,17 & 49,11 \\
\hline & $600-2000 \mathrm{~kW}$ & \multicolumn{3}{|c|}{6,78} & 6,03 & 57,29 \\
\hline & ponad $2000 \mathrm{~kW}$ & \multicolumn{3}{|c|}{10,17} & 9,04 & 85,94 \\
\hline \multirow{2}{*}{ słoneczne } & naziemne & 16,96 & 16,00 & 15,02 & 13,51 & 130,37 \\
\hline & dachowe i fasadowe & 18,04 & 17,23 & 16,37 & 14,75 & 142,06 \\
\hline bioenergetyczne & na biomasę i biogaz & \multicolumn{3}{|c|}{12,38} & 11,14 & 107,57 \\
\hline geotermalne & energia geotermalna & \multicolumn{3}{|c|}{15,02} & 13,51 & 130,37 \\
\hline \multirow{3}{*}{ wodne } & do $200 \mathrm{~kW}$ & \multicolumn{3}{|c|}{17,44} & 15,72 & 151,41 \\
\hline & $200-1000 \mathrm{~kW}$ & \multicolumn{3}{|c|}{13,94} & 12,54 & 121,01 \\
\hline & $1000-10000 \mathrm{~kW}$ & \multicolumn{3}{|c|}{10,44} & 9,42 & 90,61 \\
\hline \multirow{2}{*}{$\begin{array}{l}\text { gospodarstw } \\
\text { domowych }\end{array}$} & słoneczne do $30 \mathrm{~kW}$ & 20,03 & 19,00 & 18,09 & 16,26 & 157,26 \\
\hline & wiatrowe do $30 \mathrm{~kW}$ & \multicolumn{3}{|c|}{11,63} & 10,44 & 101,14 \\
\hline
\end{tabular}

* Stawki w euro nie obejmują siłowni oddanych do użytku po 2025 roku

Źródło: opracowanie własne na podstawie danych DAEEU (2018b) 
Istotnym warunkiem rozwoju energetyki odnawialnej jest dostępność źródeł finansowania. Jak na razie, Ukraina nie może pochwalić się większymi osiągnięciami w tym zakresie, a zainteresowane osoby nie mają zbyt dużego wyboru, jeśli chodzi o liczbę instytucji czy programów wspierających finansowanie odpowiednich projektów. Ponadto ze względu na niespójną politykę regulacyjną w dziedzinie OZE instytucje finansowe, udzielające kredytów na takie projekty, zwykle wymagają dwukrotnie większego niż w państwach UE wkładu własnego z rocznym oprocentowaniem (w przypadku kredytów w dolarach amerykańskich) na poziomie 8-10\% (Andryushchenko, 2018). Większość projektów jest obecnie finansowana przez prywatne firmy z ich własnego kapitału, rzadziej z pożyczek kilku banków komercyjnych (m.in. Ukrgazbanku, Ukreximbanku oraz Oszczadbanku) oraz z wykorzystaniem wsparcia międzynarodowych organizacji finansowych w ramach ogólnych programów rozwojowych i nielicznych programów przygotowanych specjalne dla Ukrainy (MRR, 2017). Z tych ostatnich można wspomnieć o programie USELF (Ukraine Sustainable Energy Lending Facility) Europejskiego Banku Odbudowy i Rozwoju, projekcie „Rozwój infrastruktury municypalnej” Europejskiego Banku Inwestycyjnego czy o programie „Czysta produkcja” Nordyckiej Korporacji Finansowania Ochrony Środowiska Naturalnego (NEFCO).

Ogólnie należy stwierdzić, że dotychczasowy system stymulowania energetyki odnawialnej na Ukrainie, mimo licznych ograniczeń i niedociągnięć, przyniósł wymierne efekty w postaci zaistnienia, a następnie znaczącego przyśpieszenia rozwoju tego sektora. Niemniej obserwowane tempo wyraźnie ustępuje wskaźnikom innych państw europejskich. Korzystając z międzynarodowych zestawień IRENA (2018), łatwo jest obliczyć, iż udział Ukrainy w ogólnoeuropejskiej wielkości mocy zainstalowanej OZE zmalał z 1,8\% w 2008 roku do 1,3\% w 2017 roku, a w produkcji - z 1,5\% do 0,8\%. Na koniec 2017 roku na jednego mieszkańca Ukrainy przypadało zaledwie 0,15 kW zainstalowanej mocy oraz $211 \mathrm{kWh}$ produkcji energii odnawialnej. Stosowne wartości dla kontynentu europejskiego były odpowiednio 5,8 oraz 9,4 razy wyższe, a wartości niższe od ukraińskich notowały jedynie Kosowo, Białoruś i Mołdawia.

Ostateczny sukces energetyki odnawialnej jest wypadkową wielu czynników, nie tylko natury finansowej, ale także mentalnościowej. Jak słusznie zauważają A. Kalinichenko, L. Malynska, W. Kalinichenko i N. Sazonova (2014), społeczność ukraińska raczej nie jest przygotowana do aktywnego korzystania z energii odnawialnej ze względu na przyzwyczajenie do bardzo niskich cen gazu. Jednak obserwowany obecnie stały wzrost cen paliw, który rzutuje na wszystkie dziedziny życia Ukraińców, prawdopodobnie przyśpieszy zmiany w nastawieniu obywateli. Przeprowadzone w lipcu 2018 roku badanie opinii społecznej (Reytynh, 2018) zaświadcza, że prawie 90\% respondentów ma raczej pozytywny stosunek do energetyki odnawialnej, a 75\% popiera ideę taryf gwarantowanych. Zwrócenie uwagi na wyższe ceny energii ze źródeł odnawialnych powoduje obniżenie akceptacji dla przyjętych wysokości dopłat producentom do $46 \%$ ankietowanych. Tylko 41\% respondentów deklaruje gotowość do zmniejszenia aktualnego zużycia zasobów energetycznych w swoich gospodarstwach domowych, natomiast $46 \%$ ankietowanych wolałoby utrzymać ten stan na niezmiennym poziomie. We wszystkich przypadkach stosunkowo wyższą akceptację dla OZE i bardziej racjonalnego gospodarowania zasobami demonstrują mieszkańcy zachodnich i środkowych regionów Ukrainy. 
Na koniec warto jeszcze zwrócić uwagę na niewielki segment Ukraińców czerpiących bezpośrednie korzyści z wykorzystania OZE. Chodzi o gospodarstwa domowe, posiadające własne instalacje wytwarzające energię ze źródeł odnawialnych. Jak wynika z oficjalnych danych (DAEEU, 2018c) według stanu na 30 września 2018 roku, 6031 gospodarstw domowych miało zamontowane przydomowe elektrownie słoneczne o łącznej mocy $121 \mathrm{MW}$ i mogło korzystać z dopłat gwarantowanych. Jest to zaledwie 0,04\% wszystkich takich gospodarstw, jednak średnie tempo wzrostu wynosi $43,1 \%$ na kwartał. Najbardziej zaangażowani są mieszkańcy regionu kijowskiego (12,1\% wszystkich gospodarstw), dniepropietrowskiego $(11,5 \%)$ oraz tarnopolskiego $(8,7 \%)$.

\section{PoDSUMOWANIE}

Uznanie przez władze ukraińskie rozwoju energetyki odnawialnej za jeden z kluczowych priorytetów dalszego funkcjonowania krajowego sektora energetycznego wynika nie tylko z naturalnego postępu w technice i technologii wytwarzania energii, ale również z przyjętych zobowiązań, które mają uwiarygadniać Ukrainę na arenie międzynarodowej i przedstawiać jako kraj otwarty i nowoczesny. Niestety, znaczenie OZE w miksie energetycznym Ukrainy jest nadal znikome. Dotyczy to zarówno wykorzystania potencjału technicznego (5\%), mocy zainstalowanej (14,3\%), jak i udziału w strukturze produkcji energii $(8,4 \%)$. Jeszcze mniej udanie przedstawiają się dwa ostatnie mierniki w przeliczeniu na jednego mieszkańca na tle państw Wspólnoty. Niemniej oszacowany potencjał techniczny OZE w perspektywie długookresowej winien przynieść Ukrainie wymierne korzyści. Istnieje jednak wiele czynników, zwłaszcza pozarynkowych (np. oligarchizacja i upolitycznienie sektora), których ostateczny wpływ na ukraiński rynek energetyczny jest trudny do ustalenia, stąd duże rozbieżności w możliwych scenariuszach dalszego rozwoju.

Rozkład przestrzenny produkcji energii ze źródeł odnawialnych, zarówno gdy chodzi o jej wielkość sumaryczną, jak i o strukturę rodzajową, wykazuje znaczące zróżnicowanie, będące konsekwencją zróżnicowania potencjału OZE. Ten z kolei jest determinowany czynnikami natury przyrodniczej oraz ekonomiczno-technicznej. Stąd prawidłowość, że największe wartości mocy zainstalowanej i produkcji energii elektrycznej pochodzącej z OZE związane są z południową i południowo-wschodnią częścią kraju. To właśnie tu występują najkorzystniejsze warunki dla pozyskiwania energii głównie z wiatru oraz promieniowania słonecznego. Jakkolwiek nie można zapomnieć, że istotna część z tych zdolności jest obecnie niedostępna dla Ukrainy ze względu na sytuację polityczną na Krymie i Donbasie.

Istotnym warunkiem dalszego rozwoju energetyki odnawialnej na Ukrainie jest dostępność źródeł finansowania. Niestety, państwowe wsparcie instytucjonalne, w tym finansowe, dla tego typu inwestycji jest bardzo ograniczone tak pod względem skali, formy i miejsca, jak również czasu finansowania. Dlatego większość realizowanych projektów jest obecnie finansowana przez firmy prywatne. Może to rodzić pytania o działania monopolistyczne, ale wydaje się, że dotychczasowy system stymulowania energetyki odnawialnej przyniósł wymierne efekty w postaci zaistnienia, a następnie znaczącego przyśpieszenia, dlatego na tym etapie rozwoju nikt takich pytań nie stawia.

Ważną rolę w ocenie rozwoju energetyki odnawialnej na Ukrainie odgrywa również czynnik behawioralny. Przy czym dotyczy on zarówno władz centralnych (prowadzenie bieżącej i projektowanie przyszłej polityki energetycznej kraju), władz 
lokalnych i regionalnych (m.in. wspieranie inicjatyw oddolnych, realizowanie zadań zleconych przez władze centralne, upowszechnianie wiedzy na temat OZE itd.), jak i samych mieszkańców (budowanie domowych instalacji OZE). Brak zrozumienia, a w konsekwencji brak współdziałania może być powodem hermetyzacji sektora, co prowadzi do czerpania korzyści z OZE tylko przez wąską grupę interesariuszy i - co gorsza może rzutować na bezpieczeństwo energetyczne kraju. Dlatego istotne jest nie tylko transparentne propagowanie idei odnawialnych źródeł energii w teorii, ale również w praktyce poprzez szerokie wsparcie instytucjonalne posiadające kompetentne zasoby kadrowe, wypracowane wzorce postępowania, zdywersyfikowane źródła zasilania finansowego i przekonanie o słuszności przyjętej ścieżki rozwoju.

\section{Literatura \\ References}

Andryushchenko, K. (2018). Mizhnarodnyy dosvid zastosuvannya derzhavnykh prohram shchodo pidtrymky rozvytku vidnovlyuvanykh dzherel enerhiyi [Doświadczenie międzynarodowe w zakresie wykorzystania programów państwowych wspierających rozwój odnawialnych źródeł energii]. Derzhavne upravlinnya: udoskonalennya ta rozvytok, 6. Pozyskano z http://www.dy.nayka.com.ua/pdf/6_2018/3.pdf

DAEEU (2018a, 10 grudnia). Tekhnichno-dosyazhnyy potentsial vyroblennya enerhonosiyiv $\mathrm{z}$ vidnovlyuvanykh dzherel enerhiyi ta alternatyvnykh. Derzhavne ahentstvo z enerhoefektyvnosti ta enerhozberezhennya Ukrayiny [Potencjał techniczny wytwarzania energii ze źródeł odnawialnych i alternatywnych. Państwowa Agencja Efektywności Energetycznej i Energooszczędności Ukrainy]. Pozyskano z http://saee.gov.ua/uk/activity/vidnovlyuvana-enerhetyka/potentsial

DAEEU (2018b, 15 grudnia). Zvit pro rezul'taty stymulyuvannya ta vykorystannya enerhiyi, vyroblenoyi z vidnovlyuvanykh dzherel enerhiyi, v Ukrayini za 2014-2015 rr. Derzhavne ahentstvo $\mathrm{z}$ enerhoefektyvnosti ta enerhozberezhennya Ukrayiny [Sprawozdanie z wyników stymulowania i wykorzystania energii wytwarzanej ze źródeł odnawialnych na Ukrainie w latach 2014-2015. Państwowa Agencja Efektywności Energetycznej i Energooszczędności Ukrainy]. Pozyskano z http://saee.gov.ua/sites/default/files/Report_ ES_RE_Ukraine_2014_15.pdf

DAEEU (2018c, 17 grudnia) Informatsiya shchodo potuzhnosti ta obsyahiv vyrobnytstva elektroenerhiyi obyektamy vidnovlyuvanoyi elektroenerhetyky, yakym vstanovleno «zelenyy» taryf (stanom na 30.09.2018). Derzhavne ahentstvo z enerhoefektyvnosti ta enerhozberezhennya Ukrayiny [Informacje na temat mocy zainstalowanej i wielkości produkcji energii elektrycznej na obiektach energetyki odnawialnej korzystających z zielonej taryfy (stan w dniu 30.09.2018). Państwowa Agencja Efektywności Energetycznej i Energooszczędności Ukrainy]. Pozyskano z http://saee.gov.ua/sites/default/files/VDE.pdf

DSSU (2018a, 1 grudnia). Zahalne postachannia pervynnoi enerhii za 2007-2016 roky. Derzhavna sluzhba statystyky Ukrayiny [Ogólne zaopatrzenie w energię pierwotną w latach 20072016. Państwowa Służba Statystyki Ukrainy]. Pozyskano z https://ukrstat.org/uk/operativ/operativ2016/sg/ekolog/ukr/zp_pen_u.html

DSSU (2018b, 1 grudnia). Enerhospozhyvannya na osnovi vidnovlyuvalnykh dzherel za 20072016 roky. Państwowa Służba Statystyki Ukrainy [Zużycie energii ze źródeł odnawialnych w latach 2007-2016. Państwowa Służba Statystyki Ukrainy]. Pozyskano z http://www. ukrstat.gov.ua/operativ/operativ2016/sg/ekolog/ukr/esp_vg_u.htm

EnC (2012). Decision 2012/04/MC-EnC implementing Directive 2009/28/EC on the promotion of the use of energy from renewable sources. Energy Community. Pozyskano z https://www.energy-community.org/dam/jcr:f2d4b3b8-de85-41b2-aa28-142854b65903/ Decision_2012_04_MC_RE.pdf

IEA (2018, 10 grudnia). Atlas of Energy. International Energy Agency. Pozyskano z http://energyatlas.iea.org/\#!/tellmap/-297203538/3 
IRENA (2015). REmap 2030. Renewable Energy Prospects for Ukraine. Abu Dhabi: International Renewable Energy Agency. Pozyskano z https://www.irena.org/-/media/Files/IRENA/ Agency/Publication/2015/Apr/IRENA_REmap_Ukraine_paper_2015.pdf

IRENA (2018). Renewable Energy Statistics 2018. Abu Dhabi: International Renewable Energy Agency. Pozyskano z https://www.irena.org/-/media/Files/IRENA/Agency/ Publication/2018/Jul/IRENA_Renewable_Energy_Statistics_2018.pdf

Kalinichenko, A., Malynska, L., Kalinichenko, W., Sazonova, N. (2014). Energetyka odnawialna problem czy szansa dla Ukrainy. Proceedings of ECOpole, 8(1), 181-188. Pozyskano z http:// yadda.icm.edu.pl/yadda/element/bwmeta1.element.baztech-fc4d2503-8c79-4e8e-b716-62046996afff/c/PECO_2014_1_part1-23.pdf

Kost, P. (2017). 9 „wąskich gardeł” ukraińskiej energetyki. Zagrożenie ze strony Rosji i oligarchów. Energetyka, 24. Pozyskano z https://www.energetyka24.com/9-waskich-gardel-ukrainskiej-energetyki-zagrozenie-ze-strony-rosji-i-oligarchow-analiza

Kost, P. (2018). „Odnawialna” Ukraina - nierealne ambicje. Energetyka, 24. Pozyskano z https:// www.energetyka24.com/odnawialna-ukraina--nierealne-ambicje

MRR (2017). Rozvytok vidnovlyuvanykh dzherel enerhiyi v Ukrayini. Ministerstvo rehionalnoho rozvytku, budivnytstva ta zhytlovo-komunalnoho hospodarstwa [Rozwój odnawialnych źródeł energii na Ukrainie. Ministerstwo Rozwoju Regionalnego, Budownictwa i Mieszkalnictwa oraz Usług Komunalnych Ukrainy]. Pozyskano z http://www.minregion. gov.ua/wp-content/uploads/2017/03/Rozvitok-VDE-v-Ukrai--ni.pdf

NKPEKP (2018a, 1 grudnia). Zvit pro rezultaty diyalnosti Natsionalnoyi komisiyi, shcho zdiysnyuye derzhavne rehulyuvannya u sferakh enerhetyky ta komunalnykh posluh, u 2017 rotsi. Natsionalna komisiya, shcho zdiysnyuye derzhavne rehulyuvannya u sferakh enerhetyky ta komunalnykh posluh [Sprawozdanie z wyników działalności Narodowej Komisji ds. Regulacji Energetyki i Usług Komunalnych w 2017 roku. Narodowa Komisja ds. Regulacji Energetyki i Usług Komunalnych]. Pozyskano z http://www.nerc.gov.ua/data/filearch/ Catalog3/Richnyi_zvit_NKREKP_2017.pdf

NKPEKP (2018b, 1 grudnia). Informatsiya pro obyekty alternatyvnoyi enerhetyky, yakym vstanovleno „zelenyy” taryf (stanom na 01.01.2018). Natsionalna komisiya, shcho zdiysnyuye derzhavne rehulyuvannya u sferakh enerhetyky ta komunalnykh posluh [Informacje na temat obiektów energetyki alternatywnej, które korzystają z „zielonej” taryfy (stan w dniu 01.01.2018). Narodowa Komisja ds. Regulacji Energetyki i Usług Komunalnych]. Pozyskano z http://www.nerc.gov.ua/data/filearch/elektro/energo_pidpryemstva/stat_info_zelenyi_ taryf/2017/stat_zelenyi-taryf.12-2017.pdf

NKPEKP (2018c, 18 grudnia). Informatsiya pro obyekty alternatyvnoyi enerhetyky, yakym vstanovleno „zelenyy" taryf (stanom na 01.11.2018). Natsionalna komisiya, shcho zdiysnyuye derzhavne rehulyuvannya u sferakh enerhetyky ta komunalnykh posluh [Informacje na temat obiektów energetyki alternatywnej, które korzystają z „zielonej” taryfy (stan w dniu 01.11.2018). Narodowa Komisja ds. Regulacji Energetyki i Usług Komunalnych]. Pozyskano z http://www.nerc.gov.ua/data/filearch/elektro/energo_pidpryemstva/stat_info_zelenyi_ taryf/2018/stat_zelenyi-taryf.10-2018.pdf

Nowak, Z. (2015). Niewykorzystany potencjał - odnawialne źródła energii na Ukrainie. Biuletyn Polskiego Instytutu Spraw Międzynarodowych, 38(1275), 1-2. Pozyskano z http://www. pism.pl/files/?id_plik=19600

Oharenko, Yu, Aliyeva, O. (red.) (2017). Perekhid Ukrayiny na vidnovlyuvanu enerhetyku do 2050 roku. Zvit za rezultatamy modelyuvannya bazovoho ta alternatyvnykh stsenariyiv rozvytku enerhetychnoho sektoru [Przejście Ukrainy na odnawialne źródła energii do 2050 roku. Raport z wyników symulacji podstawowego i alternatywnych scenariuszy rozwoju sektora energetycznego]. Kyyiv: Vyd-vo TOV «ART KNYHA». Pozyskano z https://ua.boell.org/sites/ default/files/perehid_ukraini_na_vidnovlyuvanu_energetiku_do_2050_roku.pdf

Reytynh (2018, 12 grudnia). Otsinky okremykh aspektiv enerhetychnoyi sfery v Ukrayini. Sotsiolohichna hrupa Reytynh [Ocena wybranych aspektów sektora energetycznego na Ukrainie. Socjologiczna Grupa Rejtyng]. Pozyskano z http://ratinggroup.ua/research/ukraine/ocenki_otdelnyh_aspektov_energeticheskoy_sfery_v_ukraine.html

Sukhodolya, O. M., Smenkovskyy, A.Yu., Shevtsov, A. I., Zemlyanyy, M.H. (2014). Stan i perspektyvy rozvytku vidnovlyuvanoyi enerhetyky v Ukrayini [Stan i perspektywy rozwoju energetyki 
odnawialnej na Ukrainie]. Kyyiv: NISD. Pozyskano z http://www.niss.gov.ua/content/articles/files/Cyxodolya_Energ-7463d.pdf

Tsentr Razumkova (2018). Rol i mistse ukrayinskoyi enerhetyky u svitovykh enerhetychnykh protsesakh. Ukrayinskyy tsentr ekonomichnykh ta politychnykh doslidzhen im. O. Razumkova [Rola i miejsce energetyki ukraińskiej w światowych procesach energetycznych. Ukraińskie Centrum Studiów Ekonomicznych i Politycznych im. O. Razumkowa]. Pozyskano z http://razumkov.org.ua/uploads/article/2018_ENERGY_PRINT.pdf

Uaenergy (2018, 15 grudnia). Komu prinadlezhat krupneyshiye solnechnyye elektrostantsii v Ukraine. Uaenergy. Energetika Ukrainy [Kto jest właścicielem największych elektrowni słonecznych na Ukrainie. Uaenergy. Energetyka Ukrainy]. Pozyskano z http://uaenergy. com.ua/post/31201/komu-prinadlezhat-krupnejshie-solnechnye/

Ukrenergo (2018). Zvit z otsinky vidpovidnosti (dostatnosti) heneruyuchykh potuzhnostey. Derzhavne pidpryyemstvo Natsionalna enerhetychna kompaniya Ukrenerho [Sprawozdanie z oceny dostępności (wystarczalności) mocy wytwórczych. Przedsiębiorstwo Państwowe Narodowa Spółka Energetyczna Ukrenergo]. Pozyskano z https://ua.energy/wp-content/ uploads/2018/11/Zvit-z-otsinky-vidpovidnosti-dostatnosti-generuyuchyh-potuzhnostej.pdf

UVEA (2018). Vitroenerhetychnyy sektor Ukrayiny 2017. Ohlyad rynku. Ukrayinska vitroenerhetychna asotsiatsiya [Sektor energetyki wiatrowej na Ukrainie 2017. Przegląd rynku. Ukraińskie Stowarzyszenie Energetyki Wiatrowej]. Pozyskano z http://uwea.com.ua/ uploads/docs/uwea_2017_report_en_web.pdf.

Zakonodavstvo Ukrayiny (2013). Enerhetychna stratehiya Ukrayiny na period do 2030 roku. Zakonodavstvo Ukrayiny [Strategia energetyczna Ukrainy na okres do 2030 r. Prawo Ukrainy] Pozyskano z http://zakon.rada.gov.ua/laws/file/text/24/f417479n5.doc

Zakonodavstvo Ukrayiny (2014). Natsionalnyy plan diy z vidnovlyuvanoyi enerhetyky na period do 2020 roku. Zakonodavstvo Ukrayiny [Krajowy plan działań w zakresie energetyki odnawialnej na okres do 2020 roku Prawo Ukrainy]. Pozyskano z http://zakon.rada.gov.ua/ laws/show/902-2014-\%D1\%80\#n10

Zakonodavstvo Ukrayiny (2017). Enerhetychna stratehiya Ukrayiny na period do 2035 roku „Bezpeka, enerhoefektyvnist, konkurentospromozhnist”. Zakonodavstvo Ukrayiny [Strategia energetyczna Ukrainy na okres do 2035 r. „Bezpieczeństwo, efektywność energetyczna, konkurencyjność”. Prawo Ukrainy]. Pozyskano z http://zakon.rada.gov.ua/laws/file/ text/58/f469391n10.pdf

Paweł Czapliński, dr hab., prof. US, Uniwersytet Szczeciński, Wydział Ekonomii, Finansów i Zarządzania, Instytut Gospodarki Przestrzennej i Geografii Społeczno-Ekonomicznej. Członek rad redakcyjnych czasopism: Prace Komisji Geografii Przemysłu Polskiego Towarzystwa Geograficznego, Przedsiębiorczość-Edukacja oraz Rocznik Naukowy Państwowego Uniwersytetu w Chersoniu - seria Geografia. Autor publikacji i monografii z zakresu transformacji struktur przestrzennych przemysłu Polski Północnej, funkcjonowania i perspektyw rozwoju przemysłu przetwórstwa rybnego w Polsce, przedsiębiorczości młodzieży i osób starszych oraz wybranych aspektów z zarządzania i administracji samorządowej.

Paweł Czapliński, professor, University of Szczecin, Faculty of Economics, Finance and Management, Institute of Spatial Management and Socio-Economic Geography. Member of the editorial board of journals: Studies of the Industrial Geography Commission of the Polish Geographical Society, Entrepreneurship - Education and Scientific Journal of the Kherson State University - Geography. Author of publications and monographs on transformation of spatial structures of industry in Northern Poland, performance and prospects of the development of the fish processing industry in Poland, entrepreneurship of young people and the elderly and some aspects of the management and administration of local government.

ORCID: 0000-0001-5093-941X

Adres/address:

Paweł Czapliński

Uniwersytet Szczeciński

Wydział Ekonomii, Finansów i Zarządzania

Instytut Gospodarki Przestrzennej i Geografii Społeczno-Ekonomicznej

Katedra Geografii Społeczno-Ekonomicznej

ul. Mickiewicza 18, 70-383 Szczecin, Polska

e-mail: pawel.czaplinski@usz.edu.pl 
Igor Kavetskyy, dr hab., prof. US, Uniwersytet Szczeciński, Wydział Ekonomii, Finansów i Zarządzania, Instytut Gospodarki Przestrzennej i Geografii Społeczno-Ekonomicznej. Zainteresowania badawcze są związane z problematyką geografii społeczno-gospodarczej i politycznej, w tym zwłaszcza geografii wyborczej, geografii usług i marketingu terytorialnego.

Igor Kavetskyy, professor, University of Szczecin, Faculty of Economics, Finance and Management, Institute of Spatial Management and Socio-Economic Geography.

\section{ORCID: 0000-0002-3516-5484}

Igor Kavetskyy

Wydział Ekonomii, Finansów i Zarządzania

Instytut Gospodarki Przestrzennej i Geografii Społeczno-Ekonomicznej

Katedra Geografii Społeczno-Ekonomicznej

ul. Mickiewicza 18, 70-383 Szczecin, Polska

e-mail: igor.kavetskyy@usz.edu.pl 